\title{
FAKTOR-FAKTOR YANG MEMPENGARUHI KEBERHASILAN RELAKTASI (STUDI KUALITATIF DI RUMAH SAKIT ST. ELISABETH SEMARANG)
}

\author{
Reny Sartika, Etika Ratna Noer ${ }^{*}$ \\ Program Studi Ilmu Gizi Fakultas Kedokteran Universitas Diponegoro \\ Jl.Dr.Sutomo No.14, Semarang, Telp (024) 8453708, Email : gizifk@undip.ac.id
}

\begin{abstract}
Background : Exclusive breast feeding's practice in Semarang was still poor. One of intervention to overcome the breast feeding failure is Relactation. Relactation is a method to restart the breast feeding that have been stopped for days, week, even month. The study aims to determine the factors influencing the successful of Relactation Methods :The study was descriptive study with qualitative approach. The study was held in St. Elisabeth Hospital Semarang. Subjects were selected using purposive sampling method. The qualitative datas were gathered by interview and obsevation.

Results : The length of the successful of Relactation in each subject (10 subjects) were different based on the length of stopped breast feeding and how often infant's stimulation was given by the mother. The predisposing factors in the successful of Relactation were mother's knowledge (definition, benefit, technique) and mother's motivation (desire, the reason). The enabling factor in the Successful of relactation on was infant's stimulation (frequency, position of baby's mouth). The reinforcing factors in the successful of Relactation were family's endorsement (accompaniment, motivation, endorsement practice) the other mother's endorsement (advice). and the other health care practitioner's endorsement (theory, motivation, problem solving, technique, direct observation)

Conclusion : Mother's motivation and infant's stimulation was the most influencing factor of the successful of Relactation
\end{abstract}

Keywords : Relactation; the successful of Relactation qualitative

\begin{abstract}
ABSTRAK
Latar Belakang : Pemberian ASI Eksklusif di kota Semarang masih tergolong rendah. Salah satu upaya untuk menanggulangi kegagalan ASI Eksklusif adalah melalui program Relaktasi. Relaktasi merupakan suatu metode untuk memulai kembali pemberian ASI yang sempat terhenti setelah beberapa hari, beberapa minggu, bahkan beberapa bulan. Tujuan penelitian ini untuk mengetahui faktor-faktor yang mempengaruhi keberhasilan Relaktasi.

Metode : Penelitian ini merupakan penelitian deskriptif dengan metode kualitatif. Penelitian dilakukan di Rumah Sakit ST. Elisabeth Semarang. Subjek dipilih secara purposive sampling. Data kualitatif diperoleh dengan wawancara dan observasi.

Hasil : Lama keberhasilan Relaktasi pada masing-masing subjek (10 subjek) berbeda-beda tergantung dari lamanya ASI berhenti dan seringnya stimulasi bayi yang ibu lakukan. Faktor pendorong dalam keberhasilan Relaktasi adalah pengetahuan ibu Relaktasi (pengertian, manfaat, teknik) dan motivasi ibu (keinginan kuat, alasan). Faktor pemungkin keberhasilan Relaktasi adalah stimulasi bayi (frekuensi, posisi mulut bayi). Faktor penguat dalam keberhasilan Relaktasi adalah dukungan tenaga kesehatan (materi, motivasi, penanganan masalah, teknik, tinjauan langsung) dukungan keluarga (keikutsertaan, motivasi, praktik dukungan) dan dukungan teman sejawat (nasehat).

Simpulan: Motivasi ibu dan stimulasi bayi merupakan faktor yang paling berpengaruh dalam keberhasilan Relaktasi
\end{abstract}

Kata Kunci : Relaktasi; Faktor-faktor yang mempengaruhi keberhasilan Relaktasi

\section{PENDAHULUAN}

Menurut WHO (World Health Organization) dan UNICEF (United Nations Emergency Children's Fund), pemberian ASI Eksklusif adalah ketika ibu menyusui secara eksklusif tanpa memberikan makanan apapun selain ASI kecuali obat selama enam bulan pertama. Pemberian ASI Eksklusif dapat membantu bayi agar dapat mencapai pertumbuhan, perkembangan dan kesehatan yang optimal karena ASI mengandung zat-zat gizi yang paling sesuai dan sempurna untuk bayi. ${ }^{1,2}$

Praktik Pemberian ASI Eksklusif di Indonesia masih tergolong rendah meskipun pemerintah sudah mengatur kebijaksanaan mengenai ASI Eksklusif dalam SK Menteri Kesehatan No. 450/Menkes/SK/IV/2004 dan PP RI Nomor 33 Tahun 2012. Rendahnya pemberian ASI 
Eksklusif ditunjukkan oleh data RISKESDAS (Riset Kesehatan Dasar) tahun 2010, dimana jumlah bayi yang mendapatkan ASI Eksklusif hingga usia 6 bulan hanya sebesar 15,3\%. Hal tersebut tidak jauh berbeda dengan kota Semarang pada tahun 2011, dimana pemberian ASI Eksklusif sebesar 45,09\%. ${ }^{3,4}$ Rendahnya pemberian ASI Eksklusif dapat disebabkan karena berbagai masalah, baik masalah pada ibu maupun bayi. Masalah tersebut dapat berupa kurangnya informasi yang diperoleh ibu tentang manfaat pemberian ASI, adanya kelainan payudara ibu, serta kesulitan menghisap yang dialami bayi. ${ }^{5}$ Salah satu upaya untuk menanggulangi kegagalan pemberian ASI Eksklusif yaitu dengan menjalani program Relaktasi.

Relaktasi adalah upaya untuk memulai kembali pemberian ASI yang sempat terhenti setelah beberapa hari, minggu, bahkan bulan. Relaktasi dapat dilakukan pada ibu yang belum pernah memberikan ASI pada bayinya dan juga dapat dilakukan pada ibu yang pernah memberikan ASI namun sempat terhenti. ${ }^{6}$ Program Relaktasi bertujuan untuk ibu yang berubah pikiran untuk menyusui kembali bayinya dengan ASI. Keberhasilan Relaktasi dipengaruhi oleh berbagai faktor, antara lain pengetahuan ibu, pendidikan ibu, usia ibu, usia bayi, motivasi ibu, stimulasi bayi, dukungan keluarga dan dukungan tenaga kesehatan. $^{6}$

Hasil penelitian Cho di Seoul, Korea pada tahun 2010, menunjukkan bahwa terdapat 63 dari 85 ibu yang berhasil melakukan Relaktasi. Penelitian ini mengungkapkan bahwa keberhasilan Relaktasi dipengaruhi oleh faktor motivasi ibu, stimulasi bayi, dukungan keluarga dan dukungan tenaga kesehatan. ${ }^{7}$

Penelitian di Indonesia tentang program Relaktasi masih sangat terbatas. Green dan Kreuter menyebutkan bahwa faktor-faktor yang berkaitan dengan prilaku hidup sehat seseorang melipti faktor pendorong, pemungkin dan penguat dimana faktor tersebut tepat digunakan untuk meneliti perilaku kesehatan individu seperti Relaktasi. Sehingga dari latar belakang tersebut, peneliti tertarik untuk melakukan penelitian yang bertujuan untuk mengetahui faktor-faktor yang mempengaruhi keberhasilan Relaktasi pada ibu yang memiliki bayi usia nol sampai empat bulan, yang akan dilaksanakan di Klinik Laktasi Rumah Sakit St. Elisabeth Semarang. Pemilihan lokasi penelitian dikarenakan Rumah Sakit St. Elisabeth merupakan salah satu Rumah Sakit yang memiliki klinik laktasi di Semarang yang terletak di pusat kota, sehingga dimungkinkan lebih banyak masyarakat yang dapat menjangkau.

\section{METODE PENELITIAN}

Penelitian ini dilaksanakan di Klinik Laktasi Rumah Sakit St. Elisabeth Semarang pada bulan Juni - Juli 2012. Penelitian ini merupakan penelitian deskriptif dengan metode kualitatif. Pemilihan metode ini diharapkan segala sesuatu yang melatarbelakangi keberhasilan Relaktasi dapat diketahui lebih jelas dan mendapatkan banyak temuan baru karena pertanyaan yang diajukan bersifat terbuka. ${ }^{8,9}$

Pengambilan subjek penelitian menggunakan metode purposive sampling yang disesuaikan dengan kriteria inklusi dan eksklusi. Kriteria inklusi antara lain ibu memiliki bayi usia 0-4 bulan, ibu tidak memiliki kelainan payudara, dan ibu bersedia mengisi informed consent. Sedangkan kriteria eksklusi antara lain ibu dan bayi meninggal dunia dan memutuskan untuk berhenti menjadi partisipan pada saat proses penelitian berlangsung.

Variabel penelitian meliputi faktor-faktor yang mempengaruhi keberhasilan Relaktasi, antara lain faktor pendorong yaitu faktor yang terdapat pada diri subjek sehingga mempengaruhi dalam praktik Relaktasi yang terdiri dari pengetahuan Relaktasi (pengertian, manfaat, teknik) dan motivasi ibu (keinginan, alasan), faktor pemungkin yaitu faktor yang memungkinkan terjadinya praktik Relaktasi yaitu stimulasi bayi (frekuensi, posisi mulut bayi) dan faktor penguat yaitu faktor yang mendorong terjadinya praktik Relaktasi mencangkup dukungan tenaga kesehatan (materi, motivasi, penanganan masalah, teknik, tinjauan langsung), dukungan keluarga (keikutsertaan, motivasi, praktik dukungan) dan dukungan teman sejawat (nasehat).

Pemilihan subjek dilakukan secara langsung terhadap identitas pasien Relaktasi (nama dan alamat) dibuku register klinik laktasi. Jumlah subjek dalam penelitian ini sebanyak 10 orang karena peneliti hanya menemukan 10 orang yang memenuhi kriteria inklusi yang ditetapkan.

Pengumpulan data dilakukan dengan teknik wawancara mendalam (indepth interview). Analisis data dilakukan dengan cara analisis isi (content analysis) yang bersifat terbuka (open ended). Tahapan analis data secara analisis isi reduksi data, penyajian data dan penarikan simpulan. Alat yang digunakan dalam penelitian ini adalah pedoman wawancara dan alat perekam suara maupun gambar. ${ }^{10}$ 
Pada penelitian kualitatif, keabsahan data dilakukan dengan menggunakan teknik triangulasi. ${ }^{8}$ Triangulasi narasumber dilakukan dengan membandingkan keterangan yang diberikan langsung oleh subjek penelitian dengan keterangan tidak langsung yang diperoleh dari petugas kesehatan dan keluarga (suami/ibu) seputar subjek.

\section{HASIL DAN PEMBAHASAN Karakteristik Subjek}

Tabel 1. Karakteristik subjek penelitian

\begin{tabular}{|c|c|c|c|c|c|}
\hline Subjek & $\begin{array}{l}\text { Usia } \\
\text { (thn) }\end{array}$ & Pendidikan & Pekerjaan & $\begin{array}{l}\text { Usia } \\
\text { Bayi } \\
\text { (bln) }\end{array}$ & Alasan relaktasi \\
\hline 1 & 30 & Sarjana & Bekerja & 3 & ASI keluar sedikit sekali \\
\hline 2 & 26 & SMA & IRT & 2 & ASI sedikit \& subjek sakit \\
\hline 3 & 29 & Sarjana & IRT & 1,5 & ASI keluar sedikit sekali \\
\hline 4 & 26 & SMA & Bekerja & 3,5 & $\begin{array}{l}\text { ASI tidak keluar sama } \\
\text { sekali }\end{array}$ \\
\hline 5 & 35 & Sarjana & Bekerja & 2 & $\begin{array}{l}\text { ASI tidak keluar sama } \\
\text { sekali }\end{array}$ \\
\hline 6 & 25 & Sarjana & IRT & 4 & ASI keluar sedikit sekali \\
\hline 7 & 27 & Sarjana & IRT & 2 & ASI keluar sedikit sekali \\
\hline 8 & 25 & SMA & IRT & 2,5 & $\begin{array}{l}\text { ASI tidak keluar sama } \\
\text { sekali }\end{array}$ \\
\hline 9 & 28 & SMA & Bekerja & 3 & $\begin{array}{l}\text { ASI tidak keluar sama } \\
\text { sekali }\end{array}$ \\
\hline 10 & 24 & Sarjana & IRT & 1 & ASI keluar sedikit sekali \\
\hline
\end{tabular}

Berdasarkan tabel.1 subjek penelitian pada pasien klinik Laktasi berjumlah 10 orang. Usia subjek berkisar antara 21-26 tahun berjumlah 5 orang, sedangkan 5 subjek lainnya berusia antara 27-35 tahun. Secara keseluruhan, usia subjek penelitian berkisar antara 20-35 tahun, dimana rentang usia ini merupakan waktu reproduksi yang sehat dan aman serta mampu memecahkan segala permasalahan yang dihadapi secara emosional untuk kehamilan, persalinan, dan menyusui. Usia yang sesuai dengan masa reproduksi sangat baik dan mendukung dalam pemberian ASI Eksklusif. ${ }^{11}$ Tidak satupun subjek dalam penelitian ini yang menyusui bayinya secara Eksklusif meskipun sebelum dan setelah melahirkan, masing-masing subjek sudah diberikan penjelasan mengenai pentingnya pemberian ASI Eksklusif oleh petugas kesehatan. Status pekerjaan 6 subjek merupakan ibu rumah tangga, sedangkan 4 subjek lainnya bekerja.

Tingkat pendidikan 4 subjek adalah SMA, sedangkan 6 subjek adalah Sarjana. Tingginya tingkat pendidikan subjek diharapkan akan lebih mudah dalam menerima dan mencari informasi baru tentang kesehatan, terutama dalam mencari cara untuk bangkit dan berusaha memberikan ASI
Eksklusif pada bayinya. Hal ini disebabkan semakin tinggi tingkat pendidikan, subjek lebih mudah dalam menerima perubahan, termasuk hal yang menyangkut tentang pemeliharaan kesehatan. Tingkat pendidikan merupakan salah satu faktor yang dapat mempengaruhi tingkat pengetahuan, karena pengetahuan subjek mengubah sikap dan perilaku yang bernilai positif. ${ }^{12}$

\section{Praktik Relaktasi}

Praktik Relaktasi dilakukan subjek di klinik Laktasi maupun di rumah subjek. Praktik Relaktasi dilakukan subjek secara terus-menerus agar kendala dalam menyusui dapat tertangani dan subjek berhasil menyusui kembali. Klinik Laktasi Rumah Sakit St. Elisabeth memiliki 1 orang konselor Laktasi, yang bertugas menangani dan membantu subjek untuk menghadapi kesulitan menyusui. Usia bayi ketika subjek melakukan praktik Relaktasi berkisar antara 1-4 bulan. Praktik Relaktasi yang dilakukan subjek dikarenakan adanya kegagalan Laktasi. Kegagalan Laktasi yang dialami pada seluruh subjek yaitu ASI yang dikeluarkan sedikit latau tidak keluar sama sekali sehingga subjek merasa khawatir nutrisi bayinya tidak terpenuhi. 
"ASI saya keluar sedikit sekali, akhirnya ya mau gak mau ya saya kasih susu formula"

SP1/30th/3 bln

"Udah di tetek in tapi bayinya nangis terus mba, mungkin karena ASI nya kosong."

SP3/29th/1,5 bln

" teruskan pernah aku sakit, gak tau ASI nya ilang sendiri"

SP2/26 th/2 bln

Praktik Relaktasi dimulai dari kedatangan subjek ke klinik Laktasi untuk mengkonsultasikan permasalan yang terjadi. Dalam keadaan ini, terjadi interaksi secara timbal balik yang membahas keluhan dan permasalahan mengenai kegagalan Laktasi. Setelah konselor mengetahui permasalahan yang terjadi pada subjek dan subjek telah mengerti penjelasan yang diberikan oleh konselor, kemudian konselor mengajak subjek untuk melakukan pemeriksaan payudara. Konselor mengarahkan subjek untuk memijat-mijat dan mengompres payudaranya untuk memperlancar aliran ASI yang tersumbat dan menggumpal hingga ASI keluar. Setelah ASI keluar meskipun sedikit, payudara selanjutnya dipompa dengan mesin pemompa ASI. Pada saat awal Relaktasi, jumlah ASI yang keluar pada masing-masing subjek berbeda-beda. Hal ini dapat dipengaruhi oleh keadaan tenang dan keyakinan diri yang kuat, sehingga akan mempengaruhi refleks let down. Apabila refleks let down ini terganggu maka pelepasan adrenalin (epinefrin) terhambat, yang menyebabkan vasokontriksi pembuluh darah alveoli, sehingga oksitosin untuk mencapai target organ mioepitelium akan terhambat. Hal inilah yang dapat menghambat pengeluaran ASI. ${ }^{1,13}$ Selain itu, asupan nutrisi yang cukup juga akan mempengaruhi jumlah produksi ASI.

Tabel 2. Keberhasilan Subjek dalam Relaktasi

\begin{tabular}{ccccc}
\hline $\begin{array}{c}\text { Subjek } \\
\begin{array}{c}\text { Penelitian } \\
\text { (SP) }\end{array}\end{array}$ & $\begin{array}{c}\text { Umur } \\
\text { Bayi (bulan) }\end{array}$ & $\begin{array}{c}\text { Waktu } \\
\text { Keberhasilan }\end{array}$ & $\begin{array}{c}\text { Jumlah ASI } \\
\text { awal Relaktasi }\end{array}$ & $\begin{array}{c}\text { Jumlah ASI setelah } \\
\text { Relaktasi }\end{array}$ \\
\hline SP1 & $1 \mathrm{bln}$ & 4x pertemuan, 2 $\mathrm{mgg}$ & $30 \mathrm{ml} / 3 \mathrm{jam}$ & $75 \mathrm{ml} / 3 \mathrm{jam}$ \\
SP2 & $2 \mathrm{bln}$ & 3x pertemuan, $1 \mathrm{bln}$ & $10 \mathrm{ml} / 3 \mathrm{jam}$ & $95 \mathrm{ml} / 3 \mathrm{jam}$ \\
SP3 & $1,5 \mathrm{bln}$ & 4x pertemuan, $1 \mathrm{bln}$ & $50 \mathrm{ml} / 3 \mathrm{jam}$ & $100 \mathrm{ml} / 3 \mathrm{jam}$ \\
SP4 & $3,5 \mathrm{bln}$ & 3x pertemuan, $1 \mathrm{bln}$ & $60 \mathrm{ml} / 3 \mathrm{jam}$ & $80 \mathrm{ml} / 3 \mathrm{jam}$ \\
SP5 & $3 \mathrm{bln}$ & 4x pertemuan, $1 \mathrm{bln}$ & $30 \mathrm{ml} / 3 \mathrm{jam}$ & $95 \mathrm{ml} / 3 \mathrm{jam}$ \\
SP6 & $3 \mathrm{bln}$ & 6x pertemuan, $1,5 \mathrm{bln}$ & $10 \mathrm{ml} / 3 \mathrm{jam}$ & $90 \mathrm{ml} / 3 \mathrm{jam}$ \\
SP7 & $2 \mathrm{bln}$ & 4x pertemuan, $1,5 \mathrm{bln}$ & $20 \mathrm{ml} / 3 \mathrm{jam}$ & $110 \mathrm{ml} / 3 \mathrm{jam}$ \\
SP8 & $2,5 \mathrm{bln}$ & 5x pertemuan, $1,5 \mathrm{bln}$ & $15 \mathrm{ml} / 3 \mathrm{jam}$ & $90 \mathrm{ml} / 3 \mathrm{jam}$ \\
SP9 & $3 \mathrm{bln}$ & 5x pertemuan, $1,5 \mathrm{bln}$ & $50 \mathrm{ml} / 3 \mathrm{jam}$ & $110 \mathrm{ml} / 3 \mathrm{jam}$ \\
SP10 & $1 \mathrm{bln}$ & 6x pertemuan, $1 \mathrm{bln}$ & 25 ml $/ 3 \mathrm{jam}$ & $100 \mathrm{ml} / 3 \mathrm{jam}$ \\
\hline
\end{tabular}

Pelaksanaan praktik Relaktasi yang disarankan konselor yaitu 1 - 2 kali dalam seminggu. Hal ini bertujuan agar perkembangan proses Relaktasi dapat ditinjau dengan baik. Subjek 2 dan 4 dalam 1 bulan hanya melakukan 3 kali kunjungan. Walaupun demikian, hal ini tidak mengganggu perkembangan praktik Relaktasi, karena di rumah, subjek selalu melaksanakan nasihat yang diberikan konselor.

Selain kepatuhan subjek akan nasehat konselor, keberhasilan Relaktasi juga dipengaruhi oleh motivasi ibu dan stimulasi bayi. Adanya dukungan keluarga, tenaga kesehatan dan teman, mempengaruhi keberhasilan Relaktasi karena seringnya kegagalan praktik Relaktasi berasal dari diri sendiri (mudah putus asa). Sehingga dengan adanya dukungan dari pihak luar, mengembalikan kepercayaan dan semangat pada diri subjek untuk tetap melanjutkan Relaktasi. Selain itu, keberhasilan Relaktasi juga ditunjang dari fasilitas yang tersedia di klinik laktasi, seperti tempat yang nyaman, suasana tenang, alat pemompa mesin dan alat peraga payudara yang memadai. ${ }^{13}$

Praktik Relaktasi yang dilakukan subjek selama dirumah sangat berpengaruh terhadap keberhasilan Relaktasi. Hal ini disebabkan subjek dapat bertemu bayinya setiap saat dirumah, sehingga stimulasi dapat terlaksana secara terusmenerus, tanpa batasan ruang dan waktu. Awalnya, subjek umumnya merasa kesulitan saat melakukan perlekatan dengan bayinya untuk menyusui. Masalah yang sering terjadi biasanya jumlah ASI 
yang keluar hanya sedikit dan bayi selalu menangis. Namun, semakin sering bayi dirangsang dengan perlekatan ke payudara ibu, produkdi ASI akan terus meningkat. ${ }^{13}$

\section{Faktor Pendorong}

\section{a. Pengetahuan Relaktasi}

Pengetahuan Relaktasi pada subjek yaitu pengetahuan tentang pengertian, manfaat dan teknik Relaktasi baik yang diperoleh secara formal di bangku sekolah, maupun non formal yang diperoleh subjek melalui pengalaman, membaca buku, dan dari orang lain. Pengetahuan tentang Relaktasi ini merupakan langkah awal subjek dalam melakukan praktik Relaktasi, karena dari sini subjek memperoleh informasi tentang apa saja yang dibutuhkan dalam keberhasilan menyusui.

Berdasarkan hasil wawancara mendalam, hanya subjek 1 yang mengetahui istilah Relaktasi, baik pengertian dan manfaat Relaktasi, sedangkan teknik Relaktasi sendiri subjek belum mengerti dengan jelas bagaimana melakukannya. Informasi yang diperoleh subjek diketahui dari internet. Sehingga dengan pengetahuan inilah terutama yang memotivasi subjek 1 untuk datang langsung keklinik Laktasi. Sedangkan 9 subjek lainnya tidak mengetahui istilah Relaktasi tetapi langsung datang ke klinik Laktasi setelah memperoleh informasi dari teman ataupun inisiatif sendiri.

\section{"Saya tau nya dari internet bahwa ada Relaktasi, Relaktasi itu proses menyusui kembali dimana nanti ASI nya dapat keluar lagi. Kalau untuk praktiknya saya belum tau mba, ini makanya saya langsung aja keklinik Laktasi"}

\section{SP1/30th/3 b/n}

\section{"yaa gak tau ya, yang saya tau ya terapi menyusui, pokoknya langsung kesini aja" \\ SP7/27 th/2 bln \\ "gak tau,saya langsung saja ke klinik ini. Dikasih penjelasan aja kalau ASI itu dapat keluar lagi apabila bayi sering dinenenin "}

SP2/26thn/2bln

Pengetahuan Relaktasi ini berkaitan erat dengan pengetahuan subjek mengenai pemberian ASI Eksklusif. Hasil wawancara dari keseluruhan subjek, subjek terpacu melakukan praktik Relaktasi karena keinginan subjek untuk menyusui kembali bayinya dan mengatasi kekecewaan terhadap kegagalan pemberian ASI Eksklusif. Berdasarkan pentingnya manfaat pemberian ASI untuk bayi, diantaranya untuk pertumbuhan, kekebalan tubuh, adanya jalinan kasih sayang antara ibu dan bayi, serta praktis dan ekonomis. ${ }^{12}$

"Kan bisa membantu kekebalan tubuh bayi, tubuh kembangnya kan lebih bagus ketimbang susu formula." $S P 2 / 26$ th/2 bln

"Oh ya tau, kalo ASI, satu hal yang dimiliki ASI yang tidak dimiliki susu formula adalah sistem kekebalan tubuh didapatkan di ASI, selain itu anak itu jadi apa ya, anak itu dapat feel nya karna kan kita sering bareng, kalo formula kan sapa sapa bisa ngasih, terus lebih gampang dalam artian begini kalo formula sering diare, tapi kalo yang ASI jarang diare gitu hampir tidak pernah, kalo virus kalo pake ASI itu jarang terkena virus."

SP1/30 th/3 bln

\section{b. Motivasi Ibu}

Motivasi subjek merupakan hal penentu awal dalam keberhasilan Relaktasi. Motivasi subjek yaitu keinginan yang kuat yang berasal dari diri subjek yang muncul karena adanya rasa bersalah tidak dapat memberikan ASI Eksklusif terhadap bayinya serta adanya keinginan untuk mempraktikkan Relaktasi sesuai dengan pengetahuan yang dimiliki. Dengan adanya motivasi pada diri subjek yang begitu kuat maka hal hal positif lain dalam praktik Relaktasi akan terlaksana dengan baik. Berdasarkan hasil wawancara, motivasi dari seluruh subjek sudah baik walaupun terkadang subjek sempat merasa putus asa. Namun keinginan kuat seluruh subjek untuk dapat menyusui kembali lebih besar daripada rasa putus asanya, sehingga subjek tetap berusaha berkali-kali melakukan Relaktasi walaupun volume ASI yang dikeluarkan masih sedikit $(<30 \mathrm{cc})$. Hal tersebut dilakukan karena subjek merasa bersalah apabila tidak dapat menyusui bayinya. Peran konselor dibutuhkan untuk memotivasi subjek saat di klinik Laktasi, sedangkan selama dirumah, subjek membutuhkan dukungan dari keluarga (suami/ibu), sehingga kecemasan dan 
ketidaknyamanan subjek saat melakukan Relaktasi dapat terabaikan.

"Gini loh mba, sayakan tahu tentang manfaat ASI itu, lah masak yaa dicuekin, lagian juga kasian liat anak saya minum susu sapi. Pokoknya selama saya mampu dan bisa mengusahakan ASI buat anak saya,yaa kenapa enggak"

SP3/29 thn/1,5 bln

"motivasi aku buat netekin kasian liat anaknya, karna itu tadi mba manfaatnya yang luar bisa buat kesehatannya besok"

SP2/26 thn $/ 2$ bln

\section{Faktor Pemungkin}

a. Stimulasi Bayi

Stimulasi bayi dilakukan subjek dengan posisi menyusui yang benar, sehingga bayi dapat menyusu dengan nyaman dan memberikan rangsangan yang kuat terhadap aerola pada payudara ibu. Posisi menyusui yang benar yaitu sebagian aerola masuk kedalam mulut bayi dan seringnya frekuensi perlekatan antara mulut bayi dengan payudara ibu (tidak kurang dari 5 kali dalam sehari) menunjang keberhasilan Relaktasi, melalui pemberian rangsangan terhadap hormon prolaktin dan oksitosin. Hormon prolaktin memproduksi ASI dalam alveolar yang dipengaruhi oleh lama dan frekuensi stimulasi/pengisapan (sucklin), sedangkan hormon oksitosin disekresi kelenjar pituitari sebagai bentuk respon adanya hisapan yang menstimulasi sel-sel mioepitel untuk mengeluarkan ASI, yang dikenal dengan milk ejection refleks atau let down refleks, sehingga ASI yang keluar dihisap bayi melalui puting payudara. Apabila bayi tidak ingin menyusu atau bayi sedang tidur, subjek menstimulasi payudaranya menggunakan pompa maupun tangan minimal 3 kali dalam sehari.

Berdasarkan hasil wawancara, pada 4 subjek (subjek 4,5,6 dan 9) mengatakan bahwa pada saat perlekatan awal antara mulut bayi dan aerola payudara, bayi selalu menangis dan tidak mau menyusu. Hal ini disebabkan karena bayi masih mengalami bingung puting dan juga ASI yang keluar masih sedikit. Namun dengan keinginan subjek yang kuat dan melakukan stimulasi bayi secara terus menerus serta penghentian pemberian susu formula dengan dot (diberikan dengan sendok) maka bayi terbiasa dengan menyusu langsung terhadap payudara ibu. Sedangkan untuk 6 subjek lainnya bayi tidak mengalami bingung puting dan dapat melakukan perlekatan dengan baik dan nyaman.

"Pokoknya sepanjang saya tidak bekerja ya selalu sama saya, ya sampe 5 kalian ya. Saya tidak pernah menghitung, tapi setiap saya ada pasti saya berikan, kalau dipompa minimal $3 x$ sehari 4 kali."

SP5/35 th/2 bln

"yang penting mah mba dinetekin terus, lama-lama dia terbiasa dan suka nempel"

SP6/25 th/4 bln

Stimulasi merupakan faktor terpenting setelah motivasi subjek yang mempengaruhi keberhasilan praktik Relaktasi. Hasil pengamatan menunjukkan apabila faktor lain mendukung namun stimulasi tidak dilakukan dengan baik maka praktik Relaktasi akan gagal. Hal ini dapat terjadi karena payudara yang sering distimulasi akan melepaskan prolaktin yang dapat merangsang pertumbuhan alveoli di payudara dan produksi ASI akan meningkat. ${ }^{6}$

\section{Faktor Penguat}

\section{a. Dukungan Keluarga}

Dukungan keluarga meningkatkan kepercayaan diri dan mengurangi kecemasan yang sering terjadi pada subjek selama praktik Relaktasi berlangsung. Berdasarkan hasil wawancara mendalam pada seluruh subjek, delapan subjek (subjek 1,2,3,6,7,8,9 dan 10) merasakan adanya dukungan dari keluarga (suami ataupun ibu), sedangkan dua subjek lainnya (subjek 4 dan 5) merasa tidak memperoleh dukungan dari keluarga (nenek). Lima dari delapan subjek (subjek 1,6,7,9 dan 10) yang memperoleh dukungan dari keluarga, merasa keluarganya sangat mendukung penuh dengan selalu memberikan nasehat, perhatian, perlindungan dan keamanan pada ibu dan bayi dalam melakukan praktik Relaktasi. Perhatian yang diberikan suami maupun ibu diwujudkan dengan cara selalu menemani subjek untuk berkonsultasi ke klinik laktasi dan setia mendengarkan setiap penjelasan yang diberikan oleh konselor. Selain itu, 
suami dan ibu (nenek) juga selalu membantu subjek dalam menghadapi permasalahan yang dialami selama menjalankan praktik Relaktasi dan bertanya kepada konselor tentang solusi apa yang dapat dilakukan untuk mengatasi masalah tersebut. Tidak hanya itu, selama dirumah, keluarga juga mendukung subjek untuk memberikan ASI Eksklusif, selalu mengingatkan dan menyediakan makanan bergizi untuk subjek dan selalu membantu subjek dalam memberikan ASI yang sudah diperas dan dibekukan dikulkas kepada bayi, baik ketika subjek sedang beristirahat maupun bekerja. Sedangkan 3 subjek lainnya (subjek 2,3 dan 8) hanya merasa didukung dengan ucapan saja, namun tidak direalisasikan dengan tindakan. Hal ini karena keluarga, baik suami maupun ibu, merasa subjek sudah memiliki pengetahuan gizi yang cukup, sehingga keluarga memberikan tanggung jawab secara penuh pada subjek untuk pemilihan makanan yang baik bagi bayinya.

"Iya saya kesini sendirian mba karna ibu ataupun suami saya kan tau saya ngerti manfaat ASI"

SP2/26 thn $/ 2$ bln

"Suami saya ya dukung aja walaupun gak nemenin, ini soalnya lagi kerja juga mba, dia juga tau kalau saya ngerti apa yang baik buat anak saya, kan tanggung jawab saya mau ngasih anak saya makan apa"

SP3/29 thn/1,5 bln

Dua subjek (subjek 4 dan 5) merasa tidak memperoleh dukungan keluarga, terutama dari ibu. Terkadang ibu menyalahkan subjek karena ASI nya tidak keluar atau keluar tetapi sedikit, sehingga bayi tetap saja menangis dan ibu dari subjek lebih memilih untuk memberikan susu formula pada bayi daripada ASI.

"iya mba mertua aku itu, kadang gak suka liat bayi aku nangis jerit-jerit, kan asinya waktu itu gak keluar-keluar, jadi aku disuruh kasih susu formula saja."

SP4/26 thn/3,5 bln

\section{b. Dukungan Tenaga Kesehatan}

Berdasarkan hasil wawancara, diketahui bahwa seluruh subjek merasa telah didukung penuh oleh tenaga kesehatan yaitu konselor Laktasi.
"Iya mba, setiap ke klinik, mesti disemangatin Suster Sampyuh, selalu dijelasin ASI itu gak mungkin gak keluar, katanya kan kalo kita berpikir positif, dan anak selalu di tetekin ASI bisa keluar, terus juga susu formulanya nanti waktu kita kasih kebayinya, mesti dikurangin sesuai ama yang ASI nya keluarin."

SP10/24th/1bln

Dukungan dari konselor, baik penjelasan, penanganan, maupun pemberian reward, sangat membantu dalam mengatasi permasalahan yang dihadapi subjek dan dukungan tersebut juga selalu memberikan kepercayaan dan melahirkan semangat baru ketika subjek merasa apa yang sudah ia lakukan selama Relaktasi sia-sia. Pemberian reward berupa pujian selalu dilakukan konselor apabila subjek mengalami peningkatan produksi ASI ataupun ketika terjadi perkembangan yang lebih baik terkait pengetahuan dan kondisi kesehatan subjek serta bayinya. Optimalnya dukungan konselor juga dirasakan oleh peneliti saat berada di klinik laktasi, dengan melihat langsung cara konselor memberikan penjelasan tentang Relaktasi secara detail kepada subjek. Tidak hanya itu, konselor juga memperagakan bagaimana posisi menyusui bayi secara benar menggunakan alat peraga, sehingga diharapkan peragaan tersebut lebih mudah untuk dimengerti, baik oleh subjek maupun keluarga yang mendampingi subjek.

\section{c. Dukungan Teman}

Dukungan teman meningkatkan kepercayaan diri seluruh subjek. Selain itu, kehadiran teman juga dijadikan sebagai tempat bagi subjek untuk bercerita dan berkeluh kesal terhadap masalah-masalah yang dialami selama proses Relaktasi berlangsung. Berdasarkan hasil wawancara, diketahui bahwa 9 subjek memperoleh informasi Relaktasi dari teman, sedangkan 1 subjek (subjek 1) mengetahui dari internet. Sebagian besar subjek memperoleh informasi dari teman karena subjek biasanya berkumpul dengan teman-temannya dalam acara tertentu.

Dukungan teman juga dijumpai saat subjek berada di klinik Laktasi, dimana dalam forum tersebut, masing-masing ibu dapat saling menceritakan pengalaman, 
keluhan serta cara untuk mengatasi masalah seputar Relaktasi. Dukungan dari teman yang memiliki kesamaan nasib yaitu merasa gagal untuk menyusui, dapat lebih meningkatkan kepercayaan diri subjek. Hal ini dikarenakan subjek merasa memiliki teman dan bukan hanya dirinya saja yang tidak dapat memberikan ASI pada bayinya. ${ }^{14}$ Namun dukungan ini sifatnya hanya pemberian nasihat sesama teman yang mengalami hal yang sama terhadap subjek tanpa ada tindakan aktif yang secara langsung membantu pasien dalam melakukan praktik Relaktasi.

"kalo aku mba, seneng ada temennya, jadinya kalo kita kumpul di klinik nanti biasanya pada cerita keluhan masing masing, dah tu cara ngatasinnya, jadi kitakan semangat mba, soalnya kalo dirumah sepi, kan sendirian, kayaknya cuma kita sendiri yang ngerasain."

S. $9 / 28 \mathrm{th} / 3 \mathrm{bln}$

\section{KETERBATASAN PENELITIAN}

Keterbatasan dalam penelitian ini merupakan faktor internal yaitu karena keterbatasan waktu maka peneliti tidak bisa melakukan pengamatan peran serta. Hal ini mengakibatkan peneliti tidak dapat mengamati secara menyeluruh tentang situasi, proses dan perilaku subjek selama proses Relaktasi. Sehingga informasi hanya didapatkan dari wawancara dengan subjek.

\section{SIMPULAN}

Keberhasilan Relaktasi dipengaruhi oleh motivasi ibu (keinginan, alasan), stimulasi bayi (frekuensi, posisi mulut bayi), dukungan keluarga (keikutsertaan, motivasi, praktik dukungan), dukungan tenaga kesehatan (materi, motivasi, penanganan masalah, teknik, tinjauan langsung) dan dukungan teman sejawat (nasehat) yang saling berhubungan. Namun dari itu semua, motivasi ibu dan stimulasi bayi merupakan faktor yang sangat berpengaruh terhadap keberhasilan Relaktasi. Karena motivasi pada diri subjek yang begitu kuat, hal hal positif lain dalam praktik Relaktasi dapat berjalan dengan baik. Sedangkan stimulasi bayi sendiri memberikan rangsangan langsung terhadap payudara subjek, sehingga ASI dapat diproduksi.

\section{SARAN}

Diperlukan penelitian lebih lanjut dengan metode lain dan variabel yang lebih beragam untuk lebih mengetahui faktor-faktor yang dapat mempengaruhi keberhasilan Relaktasi. Untuk meningkatkan keberhasilan Relaktasi stimulasi bayi harus dilakukan sesering mungkin.

\section{DAFTAR PUSTAKA}

1. Soetjiningsih. ASI; Petunjuk untuk Tenaga Kesehatan. $1^{\text {st }}$ ed. Jakarta: EGC; 1997.p.9-14.

2. World Health Organization. Exclusive Breastfeeding for Six Months Best for Babies Everywhere. Newsline of Nutrition [serial online] 2011 [cited 2012 April 15]. Available from: http://www.who.int/.../breastfeeding.../index.html/3j am

3. Dinas Kesehatan Provinsi Jawa Tengah. Profil Kesehatan Provinsi Jawa Tengah Tahun 2009. Semarang: Dinkesprov Jateng, 2009.

4. Dinas Kesehatan Kota Semarang. Laporan Program Gizi Kota Semarang Tahun 2012. Semarang. In press 2012.

5. Widiasih, Restuning. Masalah-Masalah dalam Menyusui [Makalah Seminar Managemen Laktasi]. Fakultas Ilmu Keperawatan, Universitas Padjadjaran, Bandung [serial online] 2008 [cited 2012 March 14]. Available from:

http://pustaka.unpad.ac.id/wp.../masalah masalah_dalam_menyusui.pdf

6. Collaboration of: ENN, IBFAN, Terre des hommes, UNICEF, UNHCR, WHO, WFP. Infant Feeding in Emergencies; Module 2, Version 1.0 for Health and Nutrition Workers in Emergency Situations. Relactation. Geneva: The joint statement, 2004.p.6477.

7. Cho, Su Jin, Hye Kyoung Cho, Hee Sook Lee, Keun Lee. Factors Related to Success in Relactation. Journal Korean Soc Neonatol [serial online] 2010; 17:232-8 [cited 2012 April 25].

8. Moleong, L.J. Metode Penelitian Kualitatif. Bandung : PT.Remaja Rosdakarya. 2006.p.155-244.

9. Kusnanto, H. Metode Kualitatif dalam Riset Kesehatan. Program Pascasarjana Universitas Gajah Mada. Yogyakarta. 2001. p.1-9

10. Sugiyono. Metode penelitian kuantitatif kualitatif dan R\&D. Bandug:Alfabeta; 2009.p 243-253

11. Perinasia. Melindungi, Meningkatkan dan Mendukung Menyusui. Jakarta: Bina Rupa Aksara; 2004.

12. Notoatmodjo, Soekidjo. Ilmu Perilaku Kesehatan. Jakarta: Rineka Cipta; 2010.p.20-40.

13. Roos, Jeanne Tikoalu. Indonesia Menyusui: Relaktasi dan Induksi Laktasi. Ikatan Dokter Anak Indonesia. 2010.p.131-143

14. Agarwal Anurag, Ashish Jain. Early Successful Relactation in a Case of Prolonged Lactation Failure. Indian Journal of Pediatrics [serial online] 
2010; Volume 77 [cited 2012 March 30]. Available from:

http://medind.nic.in/icb/t10/i2/icbt10i2p214.pdf

15. Hubertin, Sri Purwanti. Konsep Penerapan ASI Eksklusif. Jakarta: EGC; 2004.p.11.

16. Soekarno. Dukungan Keluarga terhadap Antenatal Care pada Wanita Kehamilan Pertama. Malang: Bappeda Kabupaten Malang; 2004. Available from: http://elib.pdii.lipi.go.id/katalog/index.php/searchkat alog/.../1101597.pdf. 